Revista de la red interuniversitaria de estudios sobre las literaturas rioplatenses contemporáneas en Francia

$18 \mid 2018$

El río y la ciudad

\title{
Imagen y figura: del río a la orilla en el proyecto de Hernán Ronsino
}

\section{Laura Gentilezza}

\section{OpenEdition}

Journals

Edición electrónica

URL: http://journals.openedition.org/lirico/6058

DOI: $10.4000 /$ lirico.6058

ISSN: 2262-8339

Editor

Réseau interuniversitaire d'étude des littératures contemporaines du Río de la Plata

\section{Referencia electrónica}

Laura Gentilezza, «Imagen y figura: del río a la orilla en el proyecto de Hernán Ronsino », Cuadernos LIRICO [En línea], 18| 2018, Puesto en línea el 15 noviembre 2018, consultado el 07 mayo 2019. URL http://journals.openedition.org/lirico/6058 ; DOI : 10.4000/lirico.6058

Este documento fue generado automáticamente el 7 mayo 2019.

\section{(c) $(1) \odot$}

Cuadernos LIRICO está distribuido bajo una Licencia Creative Commons Atribución-NoComercialSinDerivar 4.0 Internacional. 


\title{
Imagen y figura: del río a la orilla en el proyecto de Hernán Ronsino
}

\author{
Laura Gentilezza
}

Es 1968, entonces. Miguel Briante publica Hombre en la orilla. Por esos años también escriben Borges, Wernicke [...], Haroldo Conti, Juan José Saer. Es, sin dudas, una década de transición en los modos de narrar la orilla.

Hernán Ronsino, “Los bordes del río”, 2013.

1 Desde 2003, cuando publicó su primer libro, Hernán Ronsino viene construyendo un proyecto literario cuya primera etapa pareciera cerrarse en 2013 con la aparición de Lumbre. No está simplemente publicando un libro tras otro, intuye Damián Tabarovsky ${ }^{1}$ con respecto a los primeros cuatro libros que ubicaron a Ronsino en algún lugar de la literatura argentina ${ }^{2}$. Si esto es cierto, la recurrencia de elementos perceptible de un libro a otro no sólo sirve para elaborar ejes de comparación, sino que teje la trama donde se aloja un proyecto literario.

2 La progresiva circulación de sus trabajos dio lugar durante los últimos quince años a intervenciones públicas donde Ronsino ha ido delineando su figura de autor. Entrevistas, reuniones de escritores, actividades en librerías, ferias y salones del libro en América y en Europa, aulas de la universidad -como invitado y como profesor-, son algunos de los espacios desde donde esta figura circula. Es un escritor cuya intervención pública es relativamente intensa, lo que implica que sus libros y el discurso sobre su proyecto se estén escribiendo y circulen simultáneamente ${ }^{3}$.

En este discurso Ronsino hilvana a sus publicaciones el haz de un canon literario personal que enmarca la recepción de su literatura. Su discurso, sus textos y su canon comparten una preocupación por la lengua, por su forma y por la condición lingüística de los seres humanos. La cuestión de la lengua es para Ronsino un punto nodal donde se anudan proyecto literario, canon y posición de autor. Esta preocupación se formula en términos espaciales cuando Ronsino piensa la lengua con metáforas como erosión y orilla. Afirma que se propone escribir una "lengua erosionada", “orillera", marginal con respecto a la 
del centro normativo simbolizado por Buenos Aires. Es decir, escribir la lengua de Chivilcoy, su lugar natal. Una lengua que sea como "un árbol torcido, un árbol guacho"4.

Es 1966 cuando Gérard Genette afirma que las metáforas espaciales no hablan del espacio sino de otras cosas en términos de espacio y finaliza su artículo "Espace et langage" con las siguientes líneas:

Aujourd'hui la littérature -la pensée- ne se dit plus qu'en termes de distance, d'horizon, d'univers, de paysage, de lieu, de site, de chemins et de demeure: figures naïves, mais caractéristiques, figures par excellence, où le langage s'espace afin que

l'espace, en lui devenu langage, se parle et s'écrive ${ }^{5}$.

Por esos mismos años Ronsino detecta una transición en los modos de narrar el río y la orilla, según nuestro epígrafe. Esta transición transformaría, siguiendo a Genette, el modo de pensar la literatura para quien ve, en esas imágenes, metáforas espaciales. El río y la orilla serían así figuras, la forma que toma el espacio abierto entre el lenguaje real del poeta y el lenguaje virtual del sentido literal ${ }^{6}$. Los autores que llevan adelante esa transición -Briante, Borges, Wernicke, Conti, Saer- forman el canon personal donde Ronsino busca sus figuras ${ }^{7}$.

6 La imagen del río es una metáfora espacial que exhibe la figuración de los tres elementos constitutivos del proyecto: el lugar natal como locus para las ficciones, la inscripción de su nombre de autor en el canon personal y la reflexión sobre la lengua. Desde esta perspectiva me propongo rastrear esta imagen-figura en nuestro corpus de análisis tomando esos tres aspectos como base asociativa de esta metáfora espacial.

\section{Chivilcoy: del árbol al río}

7 Hernán Ronsino nació en Chivilcoy, una ciudad pampeana ubicada a 154 kilómetros al oeste de Buenos Aires. Vivió allí su infancia y adolescencia y se mudó a Buenos Aires para iniciar sus estudios universitarios. Allí atravesó la experiencia de ser un provinciano en la gran ciudad y portar consigo la marca del lugar natal, su acento. Esta experiencia en la lengua implica para él la constatación de que la pronunciación produce sentido antes que el enunciado. Muchas veces ha repetido Ronsino que en ese momento comienza a escribir. Su libro de cuentos es la primera publicación de esa escritura y sitúa el lugar y una serie de personajes que reaparecerán en las novelas. Ya en ese libro aparece el deseo de escribir esa lengua guacha a la que el tiempo le había erosionado los finales de palabras, la lengua donde se había forjado su propio acento. El nombre del lugar condensa la imagen del río y la búsqueda de esa lengua erosionada.

La palabra Chivilcoy proviene del mapuche/araucano-pampa. Mauricio Birabent recorre las hipótesis que existen sobre el origen de esa toponimia en El pueblo de Sarmiento. Chivilcoy desde sus orígenes hasta $1880^{8}$. Allí Birabent reconoce que la información sobre la etimología y la historia del nombre es escasa. Sin embargo, arriesga algunas hipótesis:

Lo único que resalta por ahora con cierta evidencia, es el origen araucano-pampa del vocablo: lo que hace pensar, que si el blanco le dio este nombre singular al nuevo territorio descubierto, fue porque estaba bajo la influencia espiritual del indio, o sencillamente porque se llamaba así cuando llegó9.

Birabent subraya la "inquietud de la toponimia acertada y expresiva" que tenían los indígenas por la cual los nombres de la región son elocuentes de las características geográficas del territorio que designan y realiza un cotejo entre los análisis morfológicos de Estanislao Zeballos, el Padre Milanesio y la Gramática araucana del Félix José de 
Augusta. Con algunas variantes todos los desgloses coinciden en que el morfema co significa agua. Así el sentido de la palabra varía entre "el todo agua", "lugar o paraje donde hay gente y agua" e incluso "mucha agua buena". El Archivo Literario de la ciudad de Chivilcoy explica la etimología del nombre de la ciudad como "Aquí, agua", "Lugar de agua buena y abundante" y "Padre de todas las aguas", por la existencia en la región de numerosos arroyos, lagunas y cañadas.

La tierra recorrida por el agua es una característica geográfica empírica del lugar natal de Ronsino y en Lumbre se manifiesta en imágenes en sentido literal. En esta novela aparecen dieciocho imágenes intercaladas con el texto. Corresponden a las fotografías de un mismo árbol, en blanco y negro, todas en un plano contrapicado. Aquí tres ejemplos:

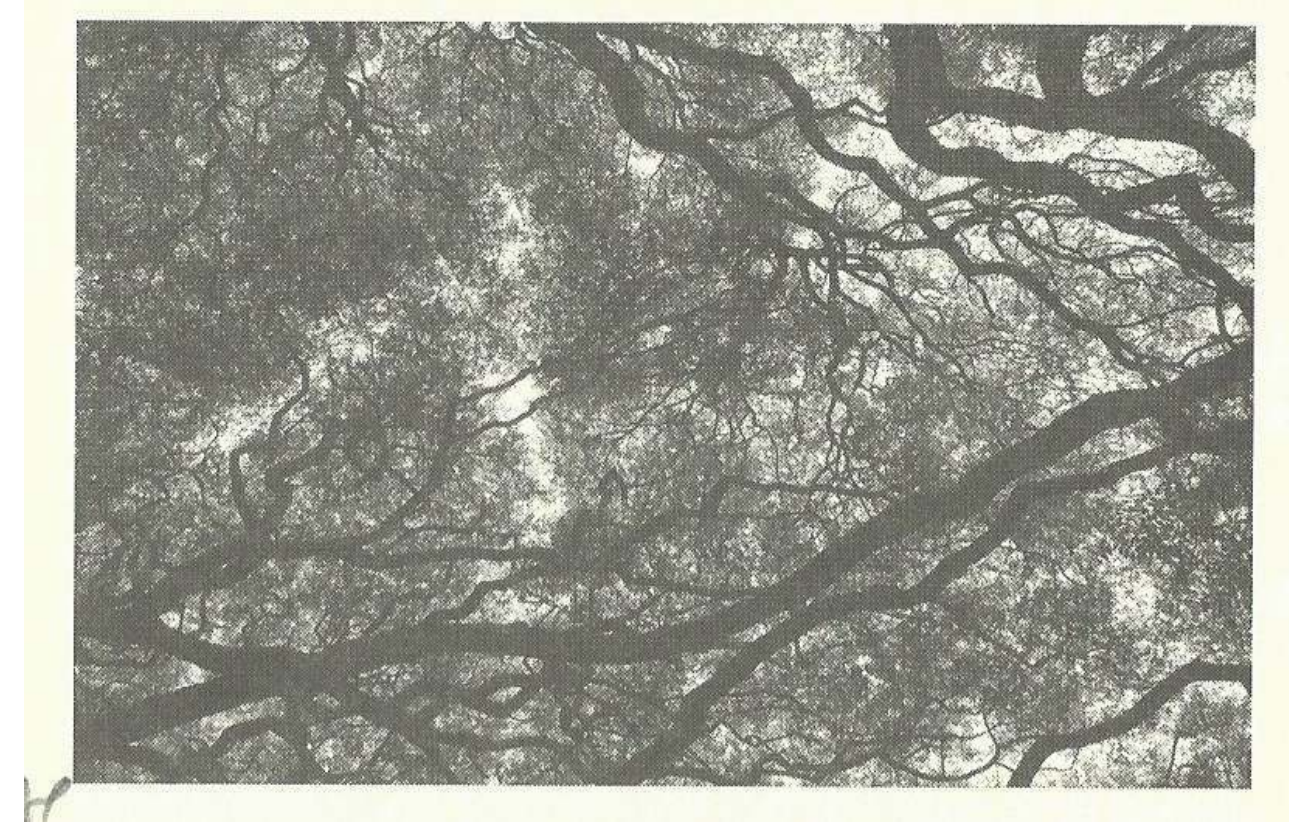




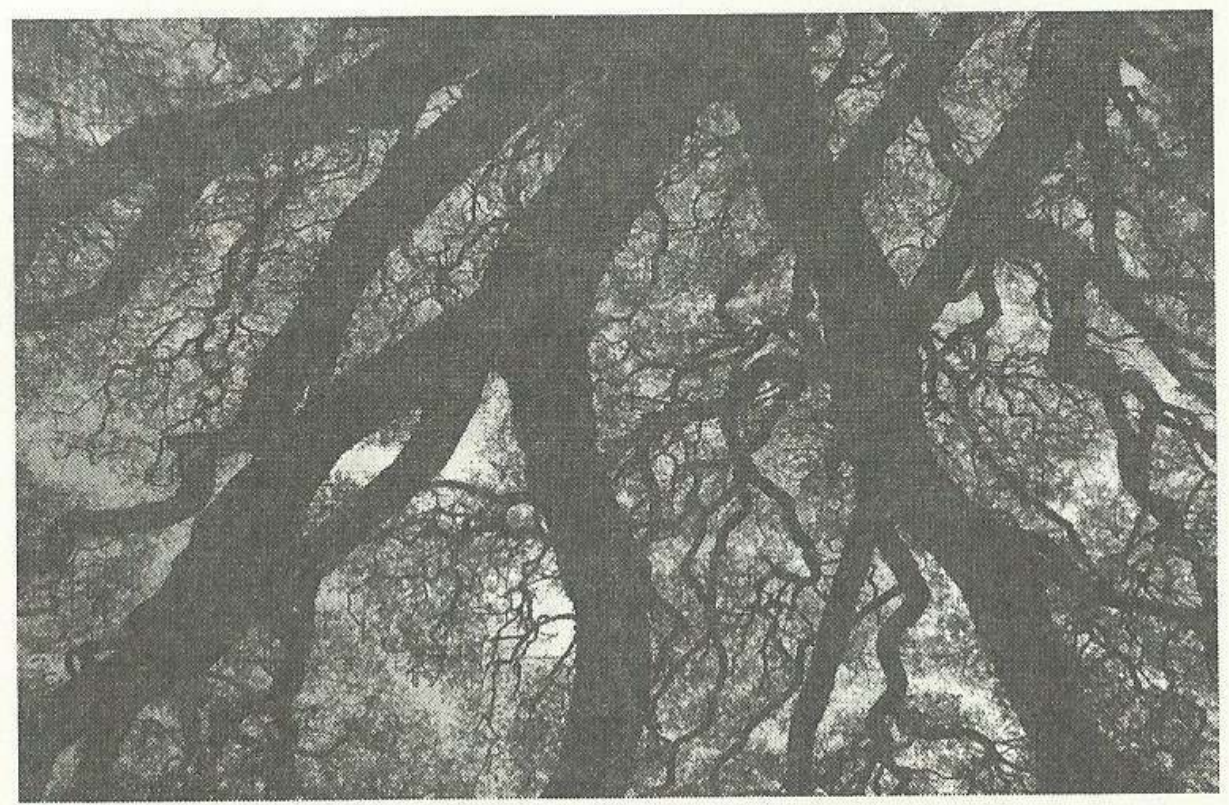

FIgURA 2: HERNÁN RONSINO, LUMBRE, P. 54.

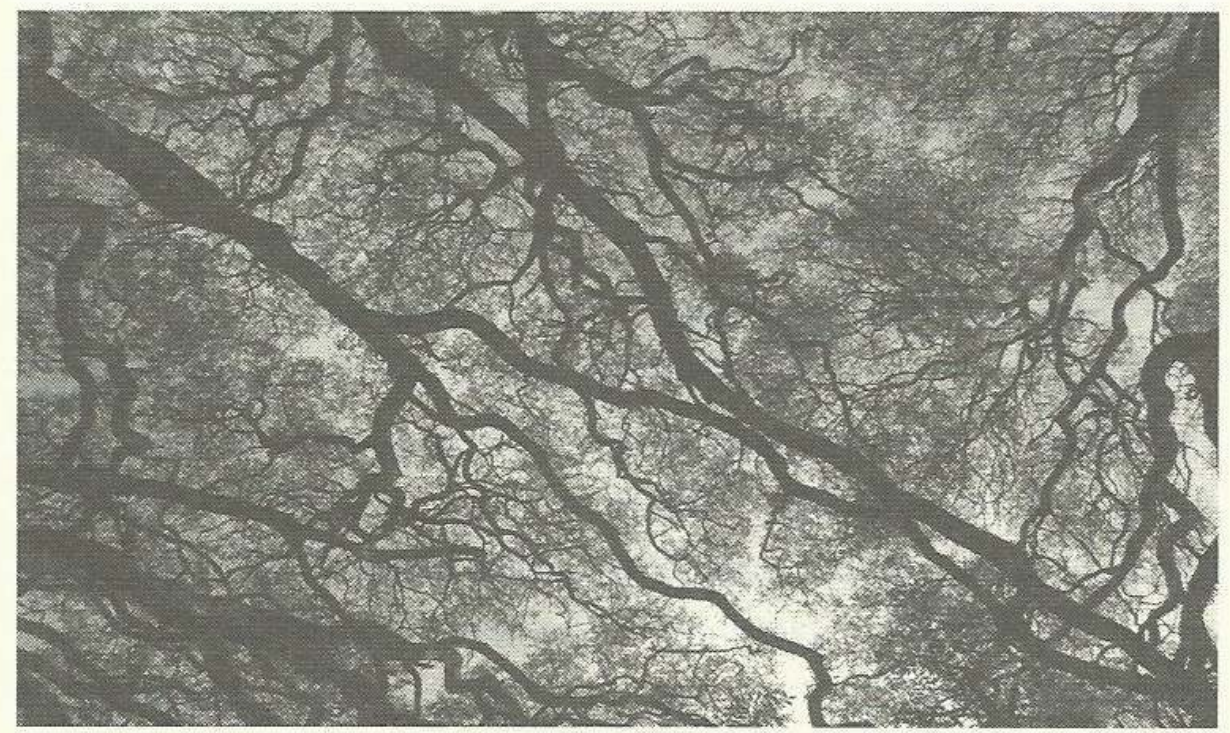

Figura 3: Hernán Ronsino, Lumbre, p. 93.

11 No vemos ni el tronco ni el tamaño del árbol, sólo el follaje y las ramas contra el cielo. Por el tamaño de las ramas más gruesas intuimos que se trata de un gran árbol, aunque la altura está aplanada por la toma en contrapicado. El blanco y negro de las fotografías se funde con el tono ahuesado del papel de la edición ${ }^{10}$, dando como resultado una opacidad cálida que recuerda las imágenes cartográficas de los antiguos diccionarios enciclopédicos de consulta escolar. Estos elementos desplazan lentamente el sentido de las imágenes que pueden ser leídas como metáforas, en sentido figurado. Si las leemos a través del título de 
la novela, Lumbre, indudablemente aparecen los ecos de Saer y de la luz atravesando las ramas en El limonero real. Pero si seguimos esta pista e invertimos el signo entre lo oscuro y lo claro, la imagen del árbol deviene río. En estas imágenes lo oscuro, las ramas del árbol, corresponden a la tierra, cuyo movimiento permanente es casi imperceptible para los seres humanos. Lo claro, en cambio, es el cielo, el aire, cuyo movimiento se siente en el cuerpo. Pero los elementos que señalamos antes -el plano y el color- nos permitirían pensar lo oscuro como cauces de agua, como ríos, y lo claro como tierra. Así se invierten los sentidos asociados a la oscuridad y a la claridad y las imágenes del árbol parecen imágenes de ríos, de cauces atravesando la tierra, en un lugar donde hay "todo agua". Donde el agua ha desbordado de su cauce, desdibujando sus bordes, como en Hombre en la orilla (Briante, 1968) y delineando un mapa de ríos, como el espacio del delta en Sudeste (Conti, 1962).

12 Estas imágenes funcionan como un corolario del trabajo de estilo de Ronsino en esta primera parte del proyecto, como si no le quedara de esa lengua erosionada, de esa lengua que es como un árbol guacho, más que condensar en las fotografías la tierra atravesada por el agua y los escritores que fraguaron la imagen del río. Las imágenes del árbol-río devienen metáfora espacial para pensar el lugar natal y leerlo así a través de esa tradición literaria.

\section{Juan Rivera: una forma llena de sentido}

13 Una década antes de publicar Lumbre, Ronsino gana el premio del Fondo Nacional de las Artes con la compilación Te vomitaré de mi boca. De ese primer libro analizaremos dos relatos, "Te vomitaré de mi boca" y "Lasteralma", porque son aquellos donde se encuentra el personaje de Juan Rivera. Este personaje aparece en el primer cuento como un bohemio y reaparece en el segundo, un relato muy breve, planteando una discusión sobre la condición lingüística de los seres humanos.

Juan Rivera y Lani conversan mientras pescan en una balsa, al estilo de los personajes de Saer: Lalo Lescano y Pichón Garay en "Discusión sobre el término zona" y Carlos Tomatis y Horacio Barco en "En la costra reseca". Juan Rivera dice que la lengua es una estafa. Lani, enojado, lo increpa: "explíqueme, qué nos está robando la palabra para que sea una estafa, qué nos está haciendo representar para que sea una farsa" ${ }^{11}$. No hay pique y no pescan nada. Rivera le pregunta a Lani a qué le suena la palabra "lasteralma". Lani contesta, separando en sílabas, como en la escuela, "las-te-ral-ma: desierto sin bordes". Cuando tocan tierra y Lani se aleja, Juan Rivera ensaya una respuesta que el otro no puede escuchar:

No tiene que creerme Lani, si estoy usando la palabra para contarle que la palabra es una estafa, una farsa, un círculo vicioso de sentido que nos vuelve animales reprimidos; esa forma llena de sentido nos separa de la naturaleza, nos impide conocer verdaderamente, nos enceguece dándonos conciencia. ¿Qué hay, entonces, detrás de las palabras? Nada. Las palabras son un barniz. Y la muerte sería un Desierto sin bordes. Qué manera, Lani, de decirme que estoy acabado, borrado, sin atributos. Estamos fritos, pero no tanto, sabe, Lani, y usted me lo acaba de demostrar. La palabra nos puede porque somos palabra ${ }^{12}$.

Nuevamente los ecos de Saer, de Conti, de Briante resuenan tanto en la escena como en el sintagma "desierto sin bordes" parecido al "río sin orillas" y "sin atributos". Pero lo relevante en este punto es lo que plantea el personaje. 
Juan Rivera propone que la palabra es una estafa porque en tanto que forma llena de sentido provoca una ruptura entre la consciencia que genera y el mundo exterior, e interfiere en la percepción. El nombre entonces es una forma llena de sentido que media en la interpretación de la realidad empírica. Juan Rivera es un nombre, una forma llena de sentido que interpretaremos de manera simbólica como mediador de la realidad empírica que describimos en el apartado anterior. Los sentidos condensados en ese símbolo reenvían al canon literario a partir del cual Ronsino diseña su proyecto.

"Te vomitaré de mi boca" cuenta la historia de Nano, un chico que vive en Chivilcoy y está confrontado a la iniciación sexual, incitado por sus amigos Ignacio y Leo, y a su primera comunión. Al pueblo llega este personaje bohemio que fascina a los tres amigos, pero especialmente a Nano que es el narrador. En la primera parte del texto la voz de Nano se funde con la de sus amigos en un nosotros indiferenciado. Una vez que sus amigos se animan a visitar el prostíbulo y Nano desiste, su voz comienza a distanciarse y recortarse de ese nosotros. Su individualidad terminará de demarcarse cuando acceda a la experiencia sexual abordado -forzado- por una prostituta vieja durante el oficio religioso de su comunión. Esto ocurre como resultado de un plan de Juan Rivera y otros personajes. Este nombre no es gratuito, sino que interpela una base asociativa vinculada con el canon personal. Por un lado, Juan es el nombre tanto de Juan José Saer como de Juan L. Ortiz. Ronsino construye un personaje donde se alinean estos dos sentidos y que fascina a su narrador Nano, cuyo nombre bien puede ser considerado un apodo de Hernán, nombre de pila de Ronsino. En la admiración de Nano por Juan está cifrado el vínculo que establece Ronsino con Saer y Saer con Juan L. Ortiz: "Saer joven estudió una forma de ver en Juan L. Ortiz, y Ronsino, en Saer", dice Beatriz Sarlo ${ }^{13}$.

Por otro lado, la palabra Rivera es un nombre común de la lengua que significa "arroyo, pequeño caudal de agua que corre por la tierra" o incluso "cauce por donde corre una rivera" según el diccionario de la Real Academia Española. Tanto Saer como Ortiz han puesto al río en el centro de gravitación de sus proyectos literarios. En la obra de Saer, dice Graciela Villanueva, el río es una constante tanto en la poesía como en la prosa, en la que ella verá una doble dimensión metatextual e intertextual. Esa intertextualidad es la que tiende el lazo hacia Juan L. Ortiz ${ }^{14}$.

Juan Rivera vive entre ríos e inicia la filiación que Ronsino busca construir a través de la imagen del río. Este nombre provoca en Nano una imagen que se repite tres veces en el cuento y que genera en el estilo un sintagma aliterado, primer esbozo de una articulación poética que podría acercarse a un verso en el trabajo de Ronsino:

Me gustó que alguien se llamara así, y además que fuera el tipo, un puro misterio. Cada vez que repetía el nombre, se me venía a la cabeza la imagen de un río: un muelle, un barco chiquito amarrado al muelle, hamacándose; un hombre sentado sobre el borde del muelle, pescando, y dejando escapar el humo del cigarrillo; y el sol, siempre a punto de esconderse, quebrado por el río, como un disco roto, centelleante.

Juan Rivera era para mí un eterno atardecer. (p. 17)

Entonces en esa especie de ensueño vi el río: un muelle, un barco chiquito, amarrado al muelle, hamacándose; un hombre sentado sobre el borde del muelle, pescando, y dejando escapar el humo del cigarrillo; y el sol, siempre a punto de esconderse, quebrado por el río, como un disco roto, centelleante. Rivera en un eterno atardecer. (p. 26-27)

[Juan Rivera] Caminaba sereno, con la valija de cuero, gastada, en una mano, hacia la estación de colectivos. Desapareció detrás de un auto. Miré el cigarrillo. Respiré su aroma. Tabaco rubio. Olor a puerto. Cerré los ojos, y volví a ver el río: un muelle, 
el barco chiquito, amarrado al muelle, hamacándose; un hombre sentado sobre el borde del muelle, pescando, y dejando escapar el humo del cigarrillo; y el sol, siempre a punto de esconderse, quebrado por el río, como un disco roto, centelleante. Descubrí, entonces, encima del banco que estaba junto al aljibe, un sobre marrón. Salí a buscarlo. Uno de los lados del sobre estaba escrito. Decía: Nano. Adentro había un cuaderno... (p. 36) historia 1 culmina con la iniciación sexual de Nano, sino para que lo escriba en un cuaderno y le pida a Nano un gesto de lectura. Leer a Juan Rivera es para Nano lo que para Ronsino fue leer a Saer -y con él a todo el canon personal-. Esta lectura abre en Ronsino un espacio literario en el sentido que le da Xavier Garnier, un efecto cuya causa se encuentra en el espacio textual, la página, pero que adviene en el acontecimiento de la lectura. "L'espace littéraire existe aux confins de deux espaces factuels bien connus: le texte et sa référence"18: para Ronsino esos dos espacios corresponden con las obras de su canon personal y su lugar natal. El espacio literario que emerge en el cruce entre esos dos elementos para este sujeto escritor es el objeto de su escritura. Ese canon personal le permite leer su lugar natal a través de esas palabras acuñadas por los autores y cargadas de sentido y luego escribir ese espacio literario mediante la ficcionalización de su lugar natal. Chivilcoy es cifra de experiencia personal y de tradición literaria y la imagen del río triangula esos dos elementos definiendo los puntos angulares donde reposan los límites de un espacio posible. El espacio literario que podemos construir los lectores de Ronsino emerge del que el mismo Ronsino experimentó leyendo a sus autores y de su deseo de écrire la lecture ${ }^{19}$.

\section{Orilleando}

Las variaciones de la imagen del río plantean maneras de pensar la relación con la lengua en este proyecto que se propone como la inscripción de la experiencia del lugar en 
función de su percepción a través de la lectura. La reaparición de personajes funda en el espacio del pueblo una genealogía presente en los cuatro libros. El personaje de Pajarito Lernú es quizás la pieza central que anuda el proyecto.

Pajarito Lernú aparece por primera vez en los cuentos "El sueño argentino" y "Secuelas de un viaje sin partida". Es el personaje que escribe, alejado de lo que podría ser el mundo literario. En La descomposición se narra que ha publicado el libro Bajo el nombre de Kafka, que se vende en dos librerías del Chivilcoy ficticio. Esta novela tiene dos partes y la primera está organizada a partir de dos ejes temporales asociados a la tipografía. Ronsino ya había utilizado las diferencias tipográficas en los cuentos sin ningún criterio aparente y en este caso le adjudica a la itálica un valor analéptico. En itálica se narra un pasado recordado y en tipografía redonda el presente de enunciación en el que el narrador, Abelardo Kieffer, está comiendo un asado con Bicho Souza para celebrar su cumpleaños.

En una de estas secuencias en itálica, Abelardo Kieffer recuerda que durante el período en que Pajarito Lernú estuvo internado en un psiquiátrico, entre 1975 y 1981, él y Bicho Souza lo visitaban regularmente para ir a pasear por el río. De esa época Abelardo conserva una imagen:

Entonces lo primero que aparece, sin saber muy bien por qué, es una imagen quieta, perdurable, como una foto: las ramas del sauce cayendo sobre el agua, se mojaban por la correntada furiosa, generalmente en las noches, del río. Y enfrente un paredón largo, con una franja blanca hasta la mitad y después, en la parte de abajo, donde recibía los golpes del agua, con cada crecida, unos cascarones brotando como manchas negras. Así, recortado por el paredón del hospital de Wagner, con medio cuerpo metido en el río, Pajarito Lernú, astillado, anémico, se movía aferrado a la caña, moroso, diminuto bajo el sol de un verano que se diferencia de todos los veranos, en principio, por esa imagen lerda, fiel, coloreada con la intensidad de lo real; tratando de perdurar, por alguna razón, en la memoria, con la contundencia y el empecinamiento que, a veces, entraña lo verdadero ${ }^{20}$.

27 Hay un cambio significativo entre esta imagen y la que comentamos más arriba: aquí el agua es penetrada mientras que en el cuento se recorría por la superficie. Ni Juan Rivera ni Lani se zambullen en el río, sino que lo navegan discutiendo, mientras que Pajarito Lernú se mete al agua. La imagen de Pajarito con el agua hasta la cintura retorna hacia el final de ese capítulo:

Eran más de las tres de la tarde cuando el botecito de López se subió a la orilla, junto al puente derrumbado. Entonces Pajarito Lernú salió del agua, dejó la postura morosa, insignificante, con la que pasó todo el día -medio cuerpo hundido en el río-, y con la que entraría en mi memoria, a pesar de su insignificancia, para perdurar, fiel, con la contundencia de lo verdadero ${ }^{21}$.

Esta modificación está asociada inmediatamente a una reflexión sobre el género. Kieffer refiere la discusión que mantuvo con Pajarito ese día, a la sombra de un árbol. En el texto hay una alternancia simétrica entre lo que dice Pajarito y lo que observa Kieffer: a Bicho Souza intentando salir del bote y llegar a tierra firme. El punto central de la reflexión de Pajarito lo constituye el género de un texto. Toma Pago chico de Roberto Payró y El pueblo de Sarmiento de Mauricio Birabent para ilustrar la diferencia entre la ficción y la historia con respecto al relato de la historia de un pueblo. Birabent se propone escribir un libro de historia y clausura el sentido del relato mientras que Payró, que escribe ficción, lo amplifica porque ese es "el atributo revolucionario de la literatura"22. Esta parte del relato de Kieffer corresponde con el momento en que Bicho Souza salta al agua y sumerge las piernas, llega a la orilla y los saluda desde el puente. Esa idea de la amplificación del sentido como revolución está asociada a la imagen de Souza metido al agua. 


\section{imaginado que irrumpe:}

Esa breve renovación, del pueblo y de uno en el pueblo, ahora, vuelve a producirse, porque yo no estuve cuando la tormenta se instaló -estaba fuera del tiempo-; no estuve cuando el pueblo se embarullaba por ese viento que, seguro, habrá cerrado las puertas y las ventanas, que habrá levantado nubes de tierra que enceguecen los ojos. Cruzo la avenida. Las luces resbalan sobre el asfalto mojado. Siento que estoy caminando en otro lugar, que estoy de viaje, que busco un restorán para cenar, que hay un río cerca, una costanera bordeada de faroles que iluminan, con manchas, los bordes del río. Pero entro a Don Pedrín ${ }^{23}$.

La imagen del río ya es, en la tercera novela, una figura a partir de la cual leer el espacio propio. Aparece explícitamente en el plano de la historia cuando la tormenta que Bicho se pierde por estar "fuera del tiempo" inaugura un clima que lo conecta directamente con un río con orillas, parecido al Paraná que narra Saer ${ }^{24}$.

Lumbre es el texto que cierra el ciclo del pueblo. Ronsino afirma que esta novela "intenta cerrar o hacer un cierre de una determinada etapa; una etapa donde ese pueblo, su pueblo, había sido el núcleo imantado alrededor del que había hecho orbitar ciertas escenas, imágenes y textos" 25 . Souza, hijo de Bicho, que vive en Buenos Aires y regresa durante tres días a pedido de su padre porque ha muerto Pajarito Lernú y le ha legado una vaca. En este retorno Federico se encontrará, además, con los cuadernos de Pajarito, Escribir de memoria. Esta circunstancia da lugar nuevamente a escenas de lectura.

La primera escena de lectura se narra en el tercer capítulo. Federico cuenta que encontró el cuaderno en el mismo lugar donde fue hallado sin vida el cuerpo de Pajarito Lernú. En lugar del cuerpo muerto, Federico obtiene un corpus de lectura: Pajarito se convierte en libro, como antes había ocurrido con Juan Rivera.

Los lectores nos encontramos luego con una de las imágenes del árbol-río que ya comentamos y la frase que encabeza todas las escenas de lectura del cuaderno: "Leo, entonces, el cuaderno de Pajarito Lernú, Escribir de memoria" ${ }^{26}$, y a continuación el texto de Pajarito Lernú que comienza en todos los casos con la evocación de la sombra. En esta primera aparición el texto es un relato que Ronsino ya había publicado en dos ocasiones: en la revista mexicana Letras Libres, en 2012, y en el diario argentino Página 12 en enero de 2017 (en este caso, cuando Lumbre ya estaba publicada y traducida). El relato se llama "A orillas del río Dyje". Cuenta la historia de un hombre, el narrador, que asesinó a su mujer y se puso a escribir durante la condena por el crimen. Una vez liberado le proponen publicar sus manuscritos y gana un premio literario. El narrador recuerda el discurso que dio durante la ceremonia de premiación: "Lo primero que expresé fue que había matado. Y mi crimen era una cantera agotada. Ahora no tenía nada más que contar. Dyje, recordé, quiere decir inerte" ${ }^{27}$.

El río Dyje existe, atraviesa la frontera entre Austria y la República Checa. Es un afluente del Morava y del Danubio. También lleva ese nombre un pueblo próximo de la misma frontera y del río. En checo, la palabra dyje quiere decir efectivamente inerte, pero si la leemos en español, la única lengua que habla Ronsino, la palabra es homófona de dije, el pretérito perfecto simple del verbo decir. A Hernán Ronsino, que solo habla español, esa toponimia le revela su posición en el proyecto y entonces "A orillas del río Dyje" se transforma en a orillas del río dije. 

que ya no se mueve, una acción finalizada como la evocada por el pretérito. Lo que dijo a orillas del río ya está terminado. La toponimia de Chivilcoy abre el proyecto tomando el río como espacio literario. Ese espacio se navega y se penetra. Se funde con la imagen del árbol poniendo en cuestión la lengua. La toponimia de Dyje representa un punto de inflexión en el trabajo sobre la lengua orillera. En la lectura de Julio Premat sobre la temporalidad en Glaxo, donde el pasado no está clausurado sino en el presente, se afirma: Lumbre cierra el ciclo del proyecto en el que el pasado aún actúa sobre el presente y Ronsino se deshace de la zona para contar otra cosa y ponerle a ese universo un punto y aparte $^{28}$. "Te vomitaré de mi boca", dan cierta imagen de circularidad y de cierre. Ahora bien, este cierre no es una clausura.

En Lumbre, la escena de lectura tiene un carácter textual en la medida en que existe tanto para el narrador como para el lector. El lector ve a través de los ojos de Federico Souza y lee el texto que aparece reproducido, a diferencia del cuento en el que los lectores accedemos al plan de Rivera por la glosa de Nano. Pero para el lector real, el que está afuera de la diégesis, ese texto es además un cuento que circula independientemente. La novela absorbe al cuento, y a la fotografía, y amplifica el sentido de esos elementos porque los inserta en una nueva trama, en un nuevo espacio textual. El cierre entonces no tiene que ver con una clausura de sentido sino con lo que Ronsino llamará la "cicatrización de la lengua", incorporando una metáfora corporal a su discurso de autor. El acento que inicialmente despertaba el deseo de escritura revela su carácter de herida en esa metáfora. La cicatrización es quizás el resultado de una fusión poética con la que Ronsino une imágenes: árbol, río, sombra. Esas imágenes le permiten hablar de otros para hablar de sí mismo y poder tener un nombre autor instalado en algún lugar de la literatura argentina, cerca de Saer, de Briante, de Conti, de Walsh.

\section{Cierres}

La orilla queda asociada a esta idea de pretérito y de cierre, es la imagen que termina de dibujar el espacio figurado donde Ronsino ubica su literatura. La figura Chivilcoy está construida a partir de dos movimientos, la fusión de imágenes y la demarcación de la voz.

Este espacio literario condensa las imágenes del río y del árbol, de la sombra y de la orilla. Se vuelve figura en el trabajo que Ronsino ha llevado adelante estos primeros diez años de proyecto (2003-2013) consagrados a escribir la lectura, a responder las preguntas que formula en Lumbre, su última novela:

¿Dónde empieza una sombra? (p. 37 y 158)

¿Cuándo empieza una sombra? (p. 93 y 256)

¿Cómo se hace, entonces, para narrar un árbol? (p. 282)

41

¿Cómo se escribe una literatura con palabras en las que ya hay inscriptos nombres propios? Esas sombras que se ciernen sobre los autores noveles que buscan quizás inscribir el propio nombre en una literatura. La poética del acento posibilita para Ronsino la diferenciación entre el escritor y el campo, entre Nano y ese nosotros en donde no tenía cuerpo propio: "Toda la inseguridad del mundo me pesó cuando esa luz, que ahora invadía mi cuerpo y afectaba mis ojos, me volvió real. Yo era real”29. Esa posición

Cuadernos LIRICO, 18 | 2018 
diferenciada se traslada a un ritmo y a una sintaxis constitutivos de la figura del narrador y es consecuencia de la experiencia en la lengua que tiene el sujeto escritor.

El río, el árbol, la sombra, la orilla llevan sobre sí una línea de significantes conformada por los autores de una literatura zonal, que se apropió de una parte de la lengua y con la que hay que lidiar si se quiere usar esas palabras. En esa línea, Ronsino va inscribiendo su nombre con una poética que discute con la escolaridad de la lengua: la ortografía, la cartografía, la separación en sílabas, los géneros, los elementos que señalan a la escuela como espacio de producción e institucionalización de una norma cultural y de una literatura nacional. En esa discusión, Ronsino afirma una literatura zonal y convierte a Chivilcoy en una figura literaria y ya no en un modelo de civilización, disputándole así el pueblo a Sarmiento.

\section{BIBLIOGRAFÍA}

Bachelard, Gaston, La poétique de l'espace, Paris, Presses Universitaires de France, [1957] 2012.

Barthes, Roland, “Écrire la lecture”, Euvres Complètes Tome II 1966-1973, Paris, Éditions du Seuil, 1993, p. 961-963.

Benoist, J. y Merlini, F., Historité et spatialité. Le problème de l'espace dans la pensée contemporaine, Paris, Vrin, 2001.

Birabent, Mauricio, El pueblo de Sarmiento. Chivilcoy desde sus orígenes hasta 1880, Chivilcoy, Municipalidad de Chivilcoy, [1938] 2012.

Briante, Miguel, Hombre en la orilla, Buenos Aires, Fondo de Cultura Económica, 2013.

Conti, Haroldo, Sudeste. Ligados, Nanterre, ALLCA XX, 2000.

Gambini, Hugo, Historia del peronismo. El poder total [1943-1951], Buenos Aires, Ediciones B, 2014.

Garnier, X. y Zoberman, P. (comps.), Qu'est-ce qu'un espace littéraire?, Saint-Denis, Presses

Universitaires de Vincennes, 2006.

Genette, Gérard, Figures 1, Paris, Éditions du Seuil, 1966.

---, Figures II, Paris, Éditions du Seuil, 1969.

Lefebvre, Herni, La production de l'espace, Paris, Editions Anthropos, 1974.

Nuevo Pequeño Diccionario ilustrado Larousse, Paris, Librairie Larousse, 1951.

Piglia, Ricardo, “Tesis sobre el cuento", Formas breves, Barcelona, Anagrama, 2000.

Premat, Julio, "Rostros partidos, rastros perdidos. Violencia y memoria en Glaxo", Revista Pandora, $\mathrm{n}^{\circ} 12,2014$.

---, “Comenzar en las Ruinas. Hernán Ronsino”, Revista Badebec, Vol. 7, Numéro 14, marzo 2018

[En ligne : https://revista.badebec.org/index.php/badebec/issue/view/14]

Ronsino Hernán, Te vomitaré de mi boca, Buenos Aires, Libris, 2003.

---, La descomposición, Buenos Aires, Interzona, 2007. 
---, Glaxo, Buenos Aires, Eterna cadencia, 2009.

---, Lumbre, Buenos Aires, Eterna cadencia, 2013.

---, Notas de campo, Buenos Aires, Excursiones, 2017.

Saer Juan José, El limonero real, Buenos Aires, Planeta/Seix Barral, [1974] 2010.

---, El Concepto de ficción, Buenos Aires, Planeta/Seix Barral, 2004.

Sarlo Beatriz, “Afinidades electivas”, Ficciones argentinas, Buenos Aires, Mar dulce, 2012.

Scott, Edgardo, “Zona traicionera: enunciación, pasado y territorio en los textos de Hernán

Ronsino”, revista El Ansia, n ำ1, octubre 2013, Buenos Aires, 2013.

Tabarovsky, Damián, “Literatura argentina reciente: cuando más marginal, más central”, revista mexicana Letras Libres, 11 de noviembre de 2014, [En línea : http://www.letraslibres.com/mexicoespana/literatura-argentina-reciente-cuanto-mas-marginal-mas-central-0]. Consultada el 2 de abril de 2017.

Villanueva, Graciela, “ ‘En un lugar arcaico y sin orillas'. Imágenes del rio en la obra de Juan Jose Saer", Sergio Delgado, Alexis Chausovsky y Guillermo Mondejar (eds.), El horizonte fluvial. Coloquio en el País del Sauce, Paraná, EDUNER, 2017.

\section{NOTAS}

1. Damián Tabarovsky, "Literatura argentina reciente: cuando más marginal, más central", revista mexicana Letras Libres, 11 de noviembre de 2014, [En línea : http://www.letraslibres.com/ mexico-espana/literatura-argentina-reciente-cuanto-mas-marginal-mas-central-0]. Consultada el 2 de abril de 2017.

2. El trabajo de Hernán Ronsino incluye la compilación de cuentos Te vomitaré de mi boca (Buenos Aires, Libris, 2003) y tres novelas: La descomposición (Buenos Aires, Interzona, 2007 y Buenos Aires, Eterna Cadencia, 2014), Glaxo (Buenos Aires, Eterna Cadencia, 2009) y Lumbre (Buenos Aires, Eterna Cadencia, 2013). Sobre este corpus extenderemos el análisis. Recientemente ha reunido los ensayos que circulaban en revistas en un volumen, Notas de campo (Buenos Aires, Excursiones, 2017). Durante la edición de este artículo se publicó su última novela, Cameron (Buenos Aires, Eterna Cadencia, 2018).

3. La presencia del trabajo de Hernán Ronsino en el campo literario no sólo se manifiesta en la publicación de textos literarios. Otros recorridos de su trabajo dan cuenta del lugar que ocupa actualmente: su identificación con la editorial Eterna Cadencia, que reeditó su primera novela, $\mathrm{La}$ descomposición, en 2014, las traducciones a siete lenguas con las que cuentan las tres novelas (francés, inglés, alemán, italiano, portugués, griego y turco), las reseñas, artículos e investigaciones que estudian sus textos. El discurso del propio Ronsino al que nos referimos está conformado por sus intervenciones en la escena pública. A las que ya mencionamos podríamos agregar las presentaciones de sus libros y de otros libros, las estadías de creación en el extranjero y los ensayos que citamos en la nota anterior. El presente artículo forma parte de una investigación doctoral que tiene como objetivo estudiar la relación del escritor con su lengua para pensar la narración con otras categorías que no sean las de narrador. Este eje nace de la lectura misma de los textos de Ronsino y articula teóricamente algunos términos del discurso que él ha forjado sobre su obra para pensar la narración sin escindir experiencia y texto, como lo hace la noción de narrador. En el transcurso de la investigación hemos realizado varias entrevistas, dos en particular que conforman un anexo a la tesis, donde Ronsino formula su 
experiencia con determinados términos que son el punto de interés de la reflexión que aquí compartimos.

4. Hernán Ronsino, "Ocho respuestas a una misma pregunta" Revista Ñ, 2 septiembre 2011, [En línea : https://www.clarin.com/rn/literatura/Encuesta_Ocho_respuestas_a_una_misma_ pregunta_0_r1Vov5p2PQl.html]. Consultado el 20 de marzo de 2013.

5. Gérard Genette, Figures 1, Paris, Éditions du Seuil, 1966, p. 108.

6. Ibidem, p. 207.

7. Además de Hombre en la orilla de Miguel Briante, en esos años Jorge Luis Borges publica Elogio de la sombra (1969), Haroldo Conti, Sudeste (1962); Enrique Wernicke, El agua (1968) - La ribera se había publicado en 1955- y Juan José Saer, Unidad de lugar (1967), Cicatrices (1969) y El limonero real (1974).

8. Ingeniero agrónomo chivilcoyano, Mauricio Birabent (1905-1982) participó activamente de la vida pública de mediados de siglo XX. En este libro, publicado por primera vez en 1938, emula el estilo de Sarmiento en Facundo para construir un sólido discurso donde narra la historia de Chivilcoy. En 1941, publicará Chivilcoy. La región y sus chacras. En los años que siguen forma parte del Consejo Agrario instaurado por Juan Domingo Perón, antes de su primera presidencia, mediante el cual Perón proyectaba un nuevo régimen jurídico con relación a los suelos- que finalmente no prosperó- en busca de la adhesión del campesinado a su movimiento. Cfr. Hugo Gambini, Historia del peronismo. El poder total [1943-1951], Buenos Aires, Ediciones B, 2014.

9. Mauricio Birabent, El pueblo de Sarmiento. Chivilcoy desde sus orígenes hasta 1880, Chivilcoy, Municipalidad de Chivilcoy, [1938] 2012, p. 13-24.

10. El Bookcel es un tipo de papel muy apto para la impresión de libros porque su tono ahuesado y su alta opacidad permiten descansar la vista durante la lectura. Estas dos características son las que provocan la impresión visual que describimos e interpretamos. Las fotografías de los árboles se funden con ese papel cuyo acabado recuerda las imágenes cartográficas de los diccionarios y de las enciclopedias impresos en blanco y negro. Aquí un ejemplo de un diccionario enciclopédico Larousse:

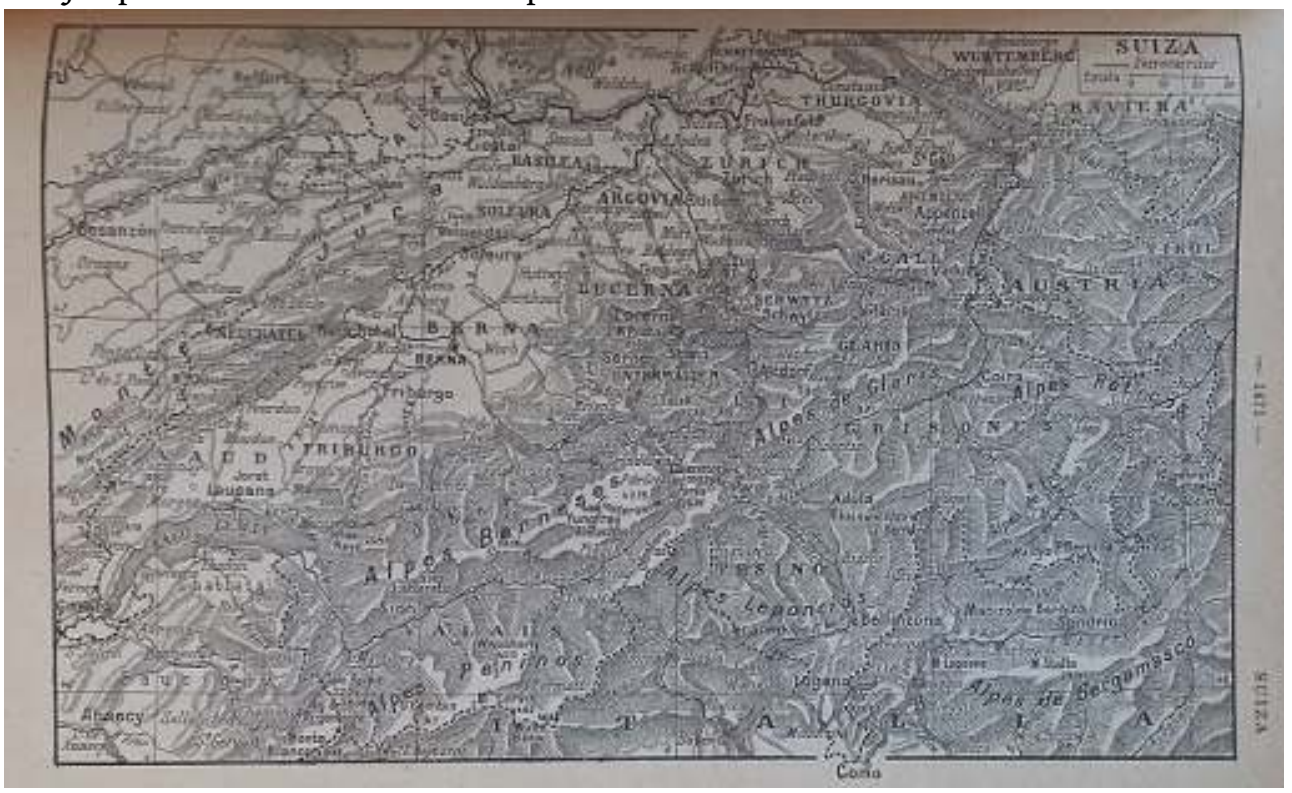

11. Hernán Ronsino, Te vomitaré de mi boca, Buenos Aires, Libris, 2003, p. 70.

12. Ibidem, p. 71.

13. Beatriz Sarlo, “Afinidades electivas", Ficciones argentinas, Buenos Aires, Mar Dulce, 2012, p. 31. 14. Graciela Villanueva, “ 'En un lugar arcaico y sin orillas'. Imágenes del río en la obra de Juan José Saer", Sergio Delgado, Alexis Chausovsky y Guillermo Mondejar (eds.), El horizonte fluvial. Coloquio en el País del Sauce, Paraná, EDUNER, 2017. 
15. Este recorrido recuerda otra referencia claramente evocada por ese nombre propio. El último texto sobre el que Rodolfo Walsh trabajó antes de ser asesinado y secuestrado por la última dictadura militar se titula "Juan se iba por el río". De un modo poético, también podríamos ver en el recorrido de Juan Rivera en esas tres imágenes el del mismo Rodolfo Walsh.

16. La doble iniciación es en realidad una sola. Ese cambio de edad que supone la primera comunión no es tal sin una inscripción en el cuerpo de orden sexual, pareciera decir el texto.

17. Ricardo Piglia, “Tesis sobre el cuento", Formas breves, Barcelona, Anagrama, 2000, p. 106.

18. X. Garnier y P. Zoberman (comps.), Qu'est-ce qu'un espace littéraire?, Saint-Denis, Presses Universitaires de Vincennes, 2006, p. 87.

19. Roland Barthes, "Écrire la lecture", Euvres Complètes Tome II 1966-1973, Paris, Éditions du Seuil, 1993, p. 961.

20. Hernán Ronsino, La descomposición, Buenos Aires, Interzona, 2007, p. 44. La imagen que conserva Abelardo es "perdurable, como una foto", la relación entre la memoria y la fotografía recorre el trabajo de Ronsino y es una cuestión que desarrollamos en el trabajo doctoral.

21. Ibidem, p. 45.

22. Ibidem, p. 48.

23. Hernán Ronsino, Glaxo, Buenos Aires, Eterna Cadencia, 2009, p. 36.

24. Recordemos que Bicho Souza es el único lector de Saer en el universo ficticio de Ronsino. En La descomposición recuerda haber leído un "libro raro sobre una familia de pescadores y un limonero" (p. 69-70), en alusión a El limonero real.

25. Edgardo Scott, "Zona traicionera: enunciación, pasado y territorio en los textos de Hernán Ronsino”, revista El Ansia, no 1, octubre 2013, Buenos Aires, 2013, p. 169.

26. Hernán Ronsino, Lumbre, Buenos Aires, Eterna Cadencia, 2013, p. 37. La frase que encabeza las cuatro escenas de lectura varía. La primera es la que acabamos de citar, en las tres siguientes desaparece el adverbio y el apellido: "Leo el cuaderno de Pajarito, Escribir de memoria" (p. 93, 158 y 256). Pero el título del cuaderno se mantiene siempre, inmediatamente después de una fotografía, lo que renueva el vínculo entre memoria y fotografía que mencionamos en una nota anterior.

27. Ibidem, p. 42.

28. Cfr. Julio Premat, "Rostros partidos, rastros perdidos. Violencia y memoria en Glaxo", Revista Pandora, no 12, 2014.

29. Hernán Ronsino, Te vomitaré de mi boca, op. cit., p. 34.

\section{RESÚMENES}

A partir de la imagen del río como figura, este artículo rastrea las huellas de los pilares que sostienen el proyecto literario del autor argentino Hernán Ronsino. La "poética del acento" y la construcción de la figura de Chivilcoy como espacio literario se anudan en esta imagen con un canon literario que conforma una "literatura zonal". Un recorrido por los primeros cuatro libros de Ronsino muestra cómo esta imagen articula la presencia de la lectura de ese canon en la escritura y busca la demarcación de una voz propia pero cercana a la de esos autores.

Partant de l'image du fleuve en tant que figure, cet article propose d'aller sur les traces des piliers qui soutiennent le projet littéraire de l'argentin Hernán Ronsino. Dans cette image du fleuve, la "poétique de l'accent" et la construction de la figure de Chivilcoy comme espace 
littéraire s'imbriquent avec un canon qui constitue une « littérature de la zone». Un parcours à travers les quatre premiers ouvrages de Ronsino permet de voir de quelle manière cette image articule la présence de la lecture de ce canon dans l'écriture et vise à la démarcation d'une voix personnelle, tout en étant proche de ces auteurs.

Based on the image of the river as a figure, this article traces the pillars of the literary project that the Argentinian author Hernán Ronsino has been building. The "poetic of the accent" and the construction of the figure of Chivilcoy as a literary space are knotted in this image with a literary canon that constitutes a "zonal literature". A tour of the first four books of Ronsino shows how this image articulates the presence of the reading of that canon in the writing and seeks the demarcation of its own voice, while being close to these authors.

ÍNDICE

Mots-clés: fleuve, figure, Ronsino, projet littéraire, bord

Keywords: river, device, Ronsino, literary project, bank

Palabras claves: río, figura, Ronsino, proyecto literario, orilla

\section{AUTOR}

LAURA GENTILEZZA

Université Paris-Est Créteil

lauragentilezza@gmail.com 